\section{Guidelines for Assessing Compost Quality for Safe and Effective Utilization in Vegetable Production}

\author{
Monica Ozores-Hampton ${ }^{1}$
}

AdDitional InDEx words. crop fertility, National Organic Program, soil improvement, sustainable production

SUMMARY. Compost is primarily a soil-amending product that may improve soil quality and the productivity of organic and conventional vegetable crops. Growers can use compost as a soil conditioner or as nutrient source to supplement the fertility program in vegetable production. Nutrients such as nitrogen, phosphorous, and potassium may be low. To lower the environmental impact of high compost application rates and protect water supplies from excessive nutrient runoff or leaching, or an excessive soil nutrient buildup, compost should be applied to match the nutrient needs of a crop. Compost quality use guidelines for assessing compost quality for use in vegetable production are limited. The objective of this paper is to present guidelines for determining compost quality for use in organic or conventional vegetable production.

$\mathrm{O}$ rganic vegetable production in the United States must comply with National Organic Program (NOP) standards [U.S. Department of Agriculture (USDA), 2016]. The NOP defines compost as the product of a managed process through which microorganisms break down plant and animal materials into more available forms suitable for application to the soil (USDA, 2016). There are no compost use quality guidelines in the NOP that address the physical, chemical, and biological properties of compost for organic vegetable production. Therefore, there is a need for more research to develop more extensive guidelines to help growers understand the potential positive and negative effects of compost in vegetable production systems. The U.S. Composting Council (USCC) developed official minimum compost use guidelines for different cropping systems (Rynk, 1992; USCC, 1996) as well as unofficial, independent compost analytical laboratories. The lack of uniform standard that limit the development of compost use guidelines is due to the

$\overline{\text { Horticultural Sciences Department, Institute of Food }}$ and Agricultural Sciences, University of Florida, Southwest Florida Research and Education Center, 2685 State Road 29 North, Immokalee, FL 34142

This paper was part of the workshop "Soil Health and Implication in Organic Nutrient Management on Vegetable Production" held 5 Aug. 2015 at the ASHS Annual Conference, New Orleans, LA, and sponsored by the Organic Horticulture Working Group.

${ }^{1}$ Corresponding author. E-mail: ozores@ufl.edu.

doi: 10.21273/HORTTECH03349-16 diversity and variability of a number of factor such as feedstocks (animal manures, food waste, yard trimming waste, agricultural by-products, etc.), composting methods (windrow, static passive or aerated piles, in vessels, etc.), application rates, application time (before or at planting), application methods (broadcast or band), crop type (fruit, leafy, stems, tubers, or roots), time of the year (fall, winter, or spring), application alone or combined with other organic or inorganic nutrient sources, etc. (Rynk, 1992; Stoffella et al., 2014). The NOP specified that compost must meet two criteria: 1) the initial carbon:nitrogen $(\mathrm{C}: \mathrm{N})$ ratio of the blended feedstocks should be between 25:1 and 40:1; and 2) the temperature must remain between 131 and $170{ }^{\circ} \mathrm{F}$ for $3 \mathrm{~d}$ in an in-vessel or static aerated pile; or $15 \mathrm{~d}$ in windrows, which must be turned at least five times during this period (USDA, 2016). The application of sewage sludge or biosolids is prohibited, whether composted or uncomposted (USDA, 2016). The definition of biosolids is a solid, semisolid, or liquid residue generated during the treatment of domestic sewage in a treatment works. Sewage sludge includes but is not limited to domestic septage; scum or solids removed in primary, secondary, or advanced wastewater treatment processes; and a material derived from sewage sludge. Also, the NOP prohibits the use of compost produced with prohibited feedstocks during the composting process, such as recycled wallboard, or any synthetic materials except those listed in the national list of synthetic substances allowed in organic production (Marriott and Zaborski, 2015).

The NOP has approved a variety of nonhazardous organic wastes that can be composted for land application to improve soil quality. These include crop residues, animal manures, food waste, yard trimming waste, and organic agricultural byproducts (Marriott and Zaborski, 2015; Stoffella et al., 2014). Proper composting, as defined by the NOP, is expected to eliminate pathogens by heat and competition with other microorganisms. Therefore, no waiting period is required between compost application, in which the soil amendment does not come in contact with the edible product, and harvest time (USDA, 2016). Commercial aerobic composting methods range from expensive operations, such as computerized in-vessel aerobic systems (turning, forced aeration, and odor control) or closed anaerobic systems, to inexpensive (manually and machine turned) windrow or static pile systems (Rynk and Richard, 2001).

Research indicates that organic waste materials suitable for composting can be beneficial to both organic and conventional vegetables growers (Ozores-Hampton, 2012; OzoresHampton et al., 2011, 2012; Rynk and Richard, 2001; Stoffella et al., 2014). Compost can be applied to improve soil physical properties

\begin{tabular}{llll}
\hline $\begin{array}{l}\text { Units } \\
\text { To convert U.S. to SI, } \\
\text { multiply by }\end{array}$ & U.S. unit & SI unit & $\begin{array}{l}\text { To convert SI to U.S., } \\
\text { multiply by }\end{array}$ \\
\hline 2.54 & inch $(\mathrm{es})$ & $\mathrm{cm}$ & 0.3937 \\
0.5933 & $\mathrm{lb} / \mathrm{yard}$ & $\mathrm{kg} \cdot \mathrm{m}^{-3}$ & 1.6856 \\
1 & $\mathrm{mmho} / \mathrm{cm}$ & $\mathrm{dS} \cdot \mathrm{m}^{-1}$ & 1 \\
28.3495 & $\mathrm{oz}$ & $\mathrm{g}$ & 0.0353 \\
1 & $\mathrm{ppm}$ & $\mathrm{mg} \cdot \mathrm{kg}^{-1}$ & 1 \\
$\left({ }^{\circ} \mathrm{F}-32\right) \div 1.8$ & ${ }^{\circ} \mathrm{F}$ & ${ }^{\circ} \mathrm{C}$ & $\left({ }^{\circ} \mathrm{C} \times 1.8\right)+32$
\end{tabular}


(water-holding capacity, soil structure, and bulk density), soil chemical properties (cation exchange capacity and plant nutrient availability) and soil biological properties [microbial activity (Ozores-Hampton et al., 2012, 2011; Stoffella et al., 2014)].

Therefore, compost is primarily a soilamending product that may improve soil quality, which eventually may improve the productivity of organic vegetable crops. Although compost is often recommended as a soil conditioner, depending on the feedstocks used to make the compost and the quality of the final product it may contain significant amounts of nutrients. Hence, testing compost quality and nutrient composition maybe relevant especially when is used to supplement the fertility program. This requires the understanding that although the contribution of nutrients such as $\mathrm{N}$ may be low, phosphorous $(\mathrm{P})$, potassium $(\mathrm{K})$, and micronutrients still should be calculated to avoid over application of nutrients (Ozores-Hampton, 2012). Higher compost application rates as a soil conditioner may produce excessive nutrient buildup in the soil and loss to the environment. In dry climates with low opportunity for nutrient loss due to leaching, high compost application rates can produce excessive salt, $\mathrm{P}$, and $\mathrm{K}$ soil accumulation that can interfere with plant growth, nutrient uptake, or cause a deficiency of other nutrients.

Compost testing is important to help growers understand compost quality and nutrient content and potential effects in their production systems. With all compost production alternatives, the compost supplier should collect a composite sample of the compost and analyze it at intervals of every 20,000 tons of compost produced or every 3 months, whichever comes first. The recommended compost testing methodologies and sampling procedures should follow the "Test Methods for the Examination of Composting and Compost" that evaluate and verify that the compost meets physical, chemical, and biological requirements (Table 1). However, it should be noted that the recommendations in Table 1 are not required by the NOP. In addition, before compost is delivered to the vegetable producer, the supplier should provide the following documentation: 1) the compost meets Federal and State health and safety regulations, 2) the composting process has met time and temperature requirements of the NOP, and 3 ) laboratory analysis that is less than 4 months old.

The objective of this paper was to collect compost quality guidelines from various sources [Cooperband, 2002; Florida Department of Environmental Protection (DEP), 2010; Marriott and Zaborski, 2015; Rynk, 1992; University of Massachusetts, 2016; U.S. Environmental Protection Agency (USEPA), 1994, 1995; USCC, 1996] and present them as a comprehensive list to help vegetable growers determine the most appropriate use of compost. These physical, chemical, and biological compost quality guidelines will promote the positive effects of compost on soil/ crops and minimize the negative impacts (environmental, crop production and growth, and others) on organic or conventional vegetable production. The development of these guidelines provides generalized information on compost quality suitable for the production of organic or conventional vegetables. Table 1 includes physical, chemical, and biological compost parameters described below.

\section{Bulk density}

Calculated as weight divided by volume. Lighter compost indicates less inorganic materials.

\section{Moisture}

Water content in the compost and is expressed as a percentage of total dry weight. Moisture content lower than $30 \%$ will indicate dry compost and higher than $60 \%$ is wet compost, which will affect handling and transportation. Dry compost will be light and dusty and wet compost will be heavy and clumpy.

\section{Organic matter}

Lower organic matter content indicates the presence of an inorganic component such as sand, clay, silt, or man-made materials such as plastics and metals.

\section{Particle size}

Particle size is determined by passing the compost through a series of sieves. Large particle size will indicate poor quality or immature compost.

\section{Physical contaminants (inert materials)}

Man-made materials that are aesthetically offensive and decrease the value of the finished compost.

\section{pH}

Most composts have the $\mathrm{pH}$ values between 5 and 8 , with a preferred ranged of 6 to 7.5.

\section{Electrical conductivity (soluble salts)}

Some specific salts (sodium and chloride) may be detrimental to vegetable crops. However, a higher electrical conductivity in most compost is due to higher nutrient content, and at recommended field application rates do not contain sufficient levels of these salts to cause phytotoxicity.

\section{Stability}

Can be defined as the point at which easily degradable $\mathrm{C}$ decrease so that its decomposition rate is no longer control the overall rate of the decomposition of the feedstocks. If the compost consumes large amount of $\mathrm{N}$ and oxygen $\left(\mathrm{O}_{2}\right)$ to support biological activity (bacteria and fungi, etc.) that can cause plant stunting by "N-immobilization." Compost stability can be determined by respiration rate by measuring the rate at which carbon dioxide is released or $\mathrm{O}_{2}$ consumed in optimal moisture and temperature conditions. Portable easy to use compost stability tests such as the Solvita maturity test (Woods End Research Laboratory, Mt Vernon, ME) are available commercially. This is a color-coded test based on a twotiered test system using respirometry (stability) and ammonia-gas emission (maturity). Very stable and mature compost will range between 7 and 8 , mature 5 to 6 , and immature $<5$.

\section{$\mathrm{C}: \mathrm{N}$ ratio}

This is the balance of the two elements for optimal performance of the compost once it is incorporated into the soil. Lower $\mathrm{C}: \mathrm{N}$ ratio may give compost an intense ammonium odor with significant losses of $\mathrm{N}$ and high $\mathrm{C}: \mathrm{N}$ ratio may immobilize $\mathrm{N}$ in the soil and cause plant stunting. 
Table 1. Optimal compost physical, chemical, and biological properties range for use in vegetable production and other production systems compiled information from various sources listed below.

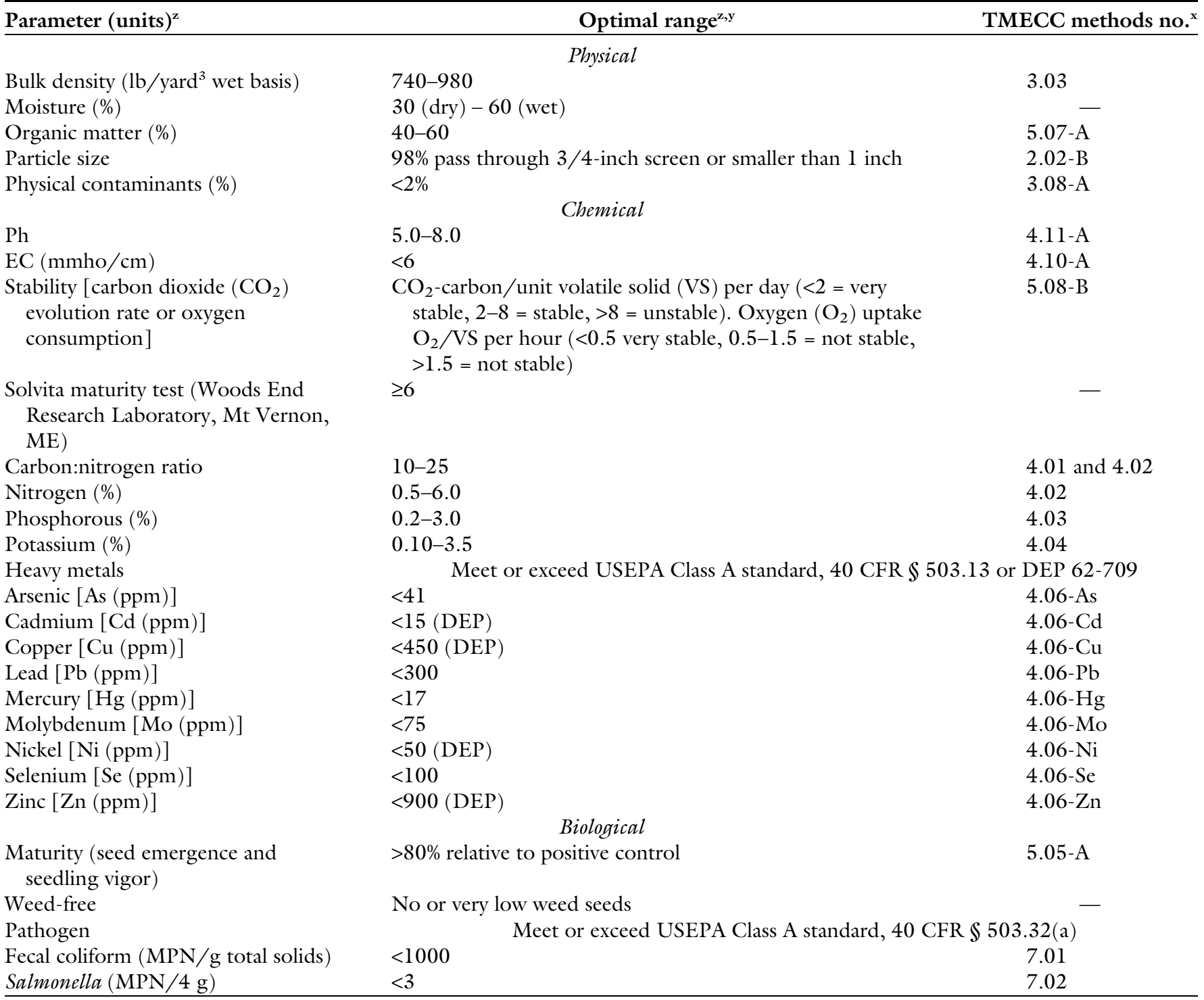

${ }_{\mathrm{z}} 1 \mathrm{lb} / \mathrm{yard}^{3}=0.5933 \mathrm{~kg} \cdot \mathrm{m}^{-3}, \mathrm{l}$ inch $=2.54 \mathrm{~cm}, 1 \mathrm{mmho} / \mathrm{cm}=1 \mathrm{mS} \cdot \mathrm{cm}^{-1}, \mathrm{l} \mathrm{ppm}=1 \mathrm{mg} \cdot \mathrm{kg}^{-1}, \mathrm{MPN}=\mathrm{most}$ probably number, $1 \mathrm{MPN} / \mathrm{g}=28.3495 \mathrm{MPN} / \mathrm{oz}, 1 \mathrm{MPN} / 4 \mathrm{~g}=$ $7.0874 \mathrm{MPN} / \mathrm{oz}$.

y Cooperband, 2002; DEP, 2010; Marriott and Zabosrski, 2015; Rynk, 1992; University of Massachusetts, 2016; USCC, 1996; USEPA, 1994, 1995.

${ }^{\mathrm{x}}$ Test methods for the examination of composting and compost.

\section{$\mathrm{N}-\mathrm{P}-\mathrm{K}$}

This is normally stipulated as a percentage of dry or wet weight. Compost $\mathrm{N}-\mathrm{P}-\mathrm{K}$ content is low compared with commercial fertilizer; however, when compost is applied at higher rates it can cause a soil nutrient buildup. The rate of $\mathrm{N}$ release or availability is especially important, since this nutrient moves readily through sandy soils. Evaluations of $\mathrm{N}$ mineralization in situ can be used to improve $\mathrm{N}$ use efficiency. However, the direct, quantitative measurement of $\mathrm{N}$ mineralization in situ is difficult due to the complex and dynamic nature of $\mathrm{N}$ transformations in the soil environment (Preusch et al., 2002).

\section{Heavy metals}

Trace elements whose concentration must meet national, state, and/or local safety standards to be marketable, due to the potential for toxicity to humans, animals, and plants.

\section{Maturity (growth screening)}

The degree to which the compost is free of phytotoxic substances, such as high ammonia levels, organic acids, and other water soluble compounds that limit seed germination and plant growth and is determined empirically using bioassay. The testing should be performed on site after compost is been delivered to the vegetable producer.

\section{Weeds-free}

Compost should not add weed seed or tubers into the soil. To produce weed-free compost, the temperature must remain between 131 and $170{ }^{\circ} \mathrm{F}$ for $3 \mathrm{~d}$ in an in-vessel or static aerated pile, or $15 \mathrm{~d}$ in windrows, which must be turned at least five times during this period (USDA, 2016).

\section{Human pathogen}

The public health needs to be protected from potential pathogen 
content, such as fecal coliform and Salmonella. Therefore, all compost that contains regulated feedstocks must meet national, state and/or local safety standards to be marketable (Cooperband, 2002; DEP, 2010; Marriott and Zaborski, 2015; Rynk, 1992; University of Massachusetts, 2016; USCC, 1996; USEPA, 1994, 1995).

Compost quality guidelines for organic vegetable production are still limited and noncomprehensive in addressing all the potential positive and negative effects of compost. However, compost physical, chemical, and biological properties presented here will promote positive effects of compost and minimize negative ones in organic and conventional vegetable production.

\section{Literature cited}

Cooperband, L. 2002. The art and science of composting. 23 Apr. 2016. <http:// www.cias.wisc.edu/wp-content/uploads/ 2008/07/artofcompost.pdf>.

Florida Department of Environmental Protection. 2010. Criteria for organic processing and recycling facilities. Chapter 62-709. 3 Feb. 2016. <https://www. flrules.org/gateway/ChapterHome.asp? Chapter $=62-709>$.

Marriott, E. and E. Zaborski. 2015. Making and using compost for organic farming. 25 Apr. 2016. <http://articles. extension.org/pages/18567/makingand-using - compost-for-organicfarming $>$.

Ozores-Hampton, M. 2012. Developing a vegetable fertility program using organic amendments and inorganic fertilizers. HortTechnology 22:743-750.

Ozores-Hampton, M., P. Roberts, and P.A. Stansly. 2012. Organic pepper production, p. 165-174. In: V. Russo (ed.). Peppers: Botany, production and uses. CABI, Cambridge, MA.

Ozores-Hampton, M., P.A. Stansly, and T. Salame. 2011. Soil chemical, physical, and biological properties of a sandy soil subjected to long-term organic amendments. J. Sustain. Agr. 35:243-259.

Preusch, P.L., P.R. Adler, L.J. Sikora, and T.J. Tworkoski. 2002. Nitrogen and phosphorus availability in composted and un-composted poultry litter. J. Environ. Qual. 31:2051-2057.

Rynk, R. 1992. On-farm composting handbook. 23 Apr. 2016. <http:// c om post.cs s.cornell. ed u/ OnFarmHandbook/onfarm_TOC.html>.

Rynk, R. and T.L. Richard. 2001. Commercial compost production systems, $\mathrm{p}$. 51-93. In: P.J. Stoffella and B.A. Kahn (eds.). Compost utilization in horticultural cropping systems. Lewis Publ., Boca Raton, FL.

Stoffella, P.J., Z.L. He, S.B. Wilson, M. Ozores-Hampton, and N.E. Roe. 2014.
Utilization of composted organic wastes in vegetable production systems. 30 Dec. 2015. <http://www.agnet.org/htmlarea file/library/20110808105418/tb147. pdfs.

University of Massachusetts. 2016. Compost and manure use and nutrients management. New England vegetable guide. 24 Apr. 2016. <https://nevegetable.org/ print/book/export/html/276>

U.S. Composting Council (USCC). 1996. Field guide to compost use. 23 Apr. 2016. <http://compostingcouncil.org/ admin/wp-content/plugins/wppdfupload/pdf/1330/Field_Guide_to_ Compost_Use.pdf $>$.

U.S. Department of Agriculture (USDA). 2016. National Organic Program. 24 Apr. 2016. <http://www.ecfr.gov/ cgi-bin $/$ text-idx? c =ecfr $\&$ sid $=3 \mathrm{f} 34 \mathrm{f} 4 \mathrm{c}$ $22 \mathrm{f} 9 \mathrm{aa} 8 \mathrm{e} 6 \mathrm{~d} 9864 \mathrm{cc} 2683 \mathrm{cea} 02 \& \mathrm{tpl}=/$ ecfrbrowse/Title07/7cfr205_main_02. tpl>.

U.S. Environmental Protection Agency (USEPA). 1994. A plain English guide to the EPA part 503 biosolids rule. EPA832R-93-003. 3 Feb. 2016. <http://www. epa.gov/biosolids/plain-english-guideepa-part-503-biosolids-rule>.

U.S. Environmental Protection Agency (USEPA). 1995. A guide to the biosolids risk assessments for the EPA part 503 rule. EPA832-B-93-005. 3 Feb. 2016. <http:// www.epa.gov/biosolids/guide-biosolidsrisk-assessment-epa-part-503-rule> . 